\title{
Cholesterol-lowering activity of lactic acid bacteria and yeast when used as probiotics in laying quail (Coturnix coturnix Japonica)
}

\author{
L. Istiqomah*, A. A. Sakti, A. Sofyan, H. Herdian and A. S. Anggraeni \\ Research Division for Natural Product Technology, Indonesian Institute of Sciences (BPTBA LIPI), \\ Gading, Playen, Gunungkidul, D.I. Yogyakarta 55861 - Indonesia \\ *Corresponding E-mail: lusty.istiqomah@gmail.com
}

Received January 14, 2020; Accepted August 01, 2020

\begin{abstract}
ABSTRAK
Penelitian ini bertujuan untuk mengetahui pengaruh pemberian Lactobacillus plantarum AKK-30 dan Saccharomyces cerevisiae B-18 sebagai probiotik dalam menurunkan kolesterol darah, telur, dan daging serta kinerja produksi puyuh petelur (Coturnix coturnix Japonica). Sebanyak 600 ekor puyuh berumur 21 hari (berat awal=101,35 $\pm 1,64 \mathrm{~g}$ ) didistribusikan dalam rancangan acak lengkap terdiri dari 5 perlakuan dan 6 ulangan. Perlakuan terdiri atas: $\mathrm{A}=$ kontrol negatif (pakan basal tanpa probiotik), $\mathrm{B}=$ $1 \%$ L. plantarum AKK-30 $\left(10^{7} \mathrm{cfu} / \mathrm{g}\right), \mathrm{C}=1 \%$ S. cerevisiae B-18 $\left(10^{6} \mathrm{cfu} / \mathrm{g}\right), \mathrm{D}=1 \%$ konsorsium probiotik, $\mathrm{E}=$ probiotik komersial. Parameter yang diamati meliputi sifat biokimia darah, kualitas produk, dan kinerja produksi. Hasil penelitian menunjukkan bahwa pemberian $1 \%$ probiotik $S$. cerevisiae (C) menghasilkan kolesterol terendah pada darah dan telur dengan kadar masing-masing $101,75 \mathrm{mg} / \mathrm{dL}$ dan $9,44 \mathrm{mg} / \mathrm{g}$, sementara pemberian 1\% probiotik L. plantarum (B) meningkatkan kadar protein dan menurunkan lemak daging $(\mathrm{P}<0,05)$. Kadar trigliserida, LDL, dan HDL darah tidak berbeda antar perlakuan. Pemberian probiotik tidak mempengaruhi kinerja pertumbuhan, produksi telur puyuh harian (QDP), konversi pakan (FCR) dan keseragaman telur. Namun, probiotik meningkatkan diameter kuning telur $(\mathrm{P}<0,05)$. Dapat disimpulkan bahwa pemberian probiotik tunggal L. plantarum AKK-30 atau $S$. cerevisiae B-18 meningkatkan kualitas produk puyuh petelur.
\end{abstract}

Kata kunci : parameter darah, kualitas telur, karkas, asimilasi kolesterol, kinerja burung puyuh

\begin{abstract}
This study aimed to evaluate the administration of Lactobacillus plantarum AKK-30 and Saccharomyces cerevisiae B-18 as probiotics in reducing cholesterol of blood, egg, and meat and also the production performance of laying quail (Coturnix coturnix Japonica). A number of 600 birds of the twenty one-day-old quails were distributed in a completely randomized design with 5 treatments and 6 replications (initial $\mathrm{BW}=101.35 \pm 1.64 \mathrm{~g}$ ). Treatments were as follows: $\mathrm{A}=$ negative control (basal diet without probiotic), B $=1 \%$ of $L$. plantarum AKK-30 $\left(10^{7} \mathrm{cfu} / \mathrm{g}\right), \mathrm{C}=1 \%$ of $S$. cerevisiae B-18 $\left(10^{6}\right.$ $\mathrm{cfu} / \mathrm{g}), \mathrm{D}=1 \%$ of a probiotic consortium, $\mathrm{E}=$ positive control (commercial probiotic). Parameters observed were blood biochemistry profiles, product quality, and production performance. The results revealed that administration of $1 \% S$. cerevisiae (C) resulted the lowest cholesterol in blood (101.75 $\mathrm{mg} / \mathrm{dL})$ and egg $(9.44 \mathrm{mg} / \mathrm{g})$ and while administration of $1 \%$ L. plantarum (B) increased meat protein and decreased fat content $(\mathrm{P}<0.05)$. Level of blood triglycerides, low-density lipoprotein (LDL), and high-density lipoprotein (HDL) were not different among treatments. Probiotic treatments did not affect the growth performance, quail day production (QDP), feed conversion ratio (FCR) and egg uniformity. However, probiotic increased diameter of egg yolk $(\mathrm{P}<0.05)$. It was concluded that administration of
\end{abstract}


single probiotic L. plantarum AKK-30 or S. cerevisiae B-18 improves the quality of laying quail products.

Keywords: blood parameters, egg quality, carcass, cholesterol-assimilation, quail performance

\section{INTRODUCTION}

Cholesterol plays an important role as a precursor in the biosynthesis of important molecules. These include bile acids (required for the digestion and absorption of dietary fat), vitamin D (necessary for calcium removal and utilization), and steroid hormones (necessary for the regulation of ion balance, metabolism, and sexual differentiation) (Sjöberg, 2016). On the other hand, the high concentration of total cholesterol is the main risk factor for coronary heart disease and stroke (Peters et al., 2016). The comparation trends in total, HDL and non-HDL cholesterol and the total-to-HDL cholesterol ratio in Asian and Western countries reported by NCD Risk Factor Collaboration/NCD-RisC (2020). They pooled 458 population-based studies with 82.1 million participants in 23 Asian and Western countries. Total cholesterol increased in all four Asian countries, with the largest increase in China and Thailand, by $0.3 \mathrm{mmol} / \mathrm{L}$ per decade (NCDRisC, 2020).

Poultry is very important as a source of animal protein because the eggs production could be reached by all levels of consumers. Some poultry commodities are quite widely raised for example chicken, duck, and quail laying eggs with a long-term of the egg production period. The production of eggs contains essential nutrients for growth, especially high protein content. However, the yolk from various poultry contains high cholesterol $16.05 \mathrm{mg} / \mathrm{g}$ on quail egg, $10.36 \mathrm{mg} / \mathrm{g}$ on a duck egg, and $7.65 \mathrm{mg} / \mathrm{g}$ on the chicken egg (Aziz et al., 2012). Therefore it is essential to minimize the cholesterol level in eggs, for instance, through the administration of microbial additives. In our previous in vitro studies, L. plantarum (Julendra et al., 2017) or $S$. cerevisiae (Istiqomah et al., 2018) as probiotics had been shown to possess cholesterol-lowering activity. The positive impact of probiotics on the performance of the laying quail was previously reported by several studies (Hosseini, 2011; Guclu, 2011; Manafi et al., 2016; Siadati et al., 2018). Kalsum et al. (2012) reported that administration of $L$. fermentum did not influence egg quality parameters and egg weight, but significantly improved total egg production and lowered cholesterol content in egg yolk. Probiotic supplementation of Lactobacillus strain reduced serum total cholesterol, low density lipoprotein (LDL) and triglyceride significantly (Lokapirnasari et al., 2018). Khalifa and Noseer (2019) reported that quail fed on combination of probiotics (L. acidophilus and S. cerevisiae) with ginger produced the lowest total cholesterol levels in serum and yolk $(107.05 \mathrm{mg} / \mathrm{dl}$ and $10.6 \mathrm{mg} / \mathrm{g})$ comparing to control group $(158 \mathrm{mg} / \mathrm{dl}$ and 14.1 $\mathrm{mg} /$ ), respectively. Generally, all the studies explored the use of the single microbial probiotic, however, effects of combining two or more microbial additives are still limited.

The current study was to evaluate the administration of Lactobacillus plantarum AKK30 and Saccharomyces cerevisiae B-18 as probiotics in reducing cholesterol of blood, egg, and meat and also the production performance of laying quail (Coturnix coturnix Japonica).

\section{MATERIALS AND METHODS}

\section{Probiotic Preparation of LAB and Yeast}

Microencapsulated culture of L. plantarum AKK-30 as probiotic was prepared by spray drying method according to Barbosa-Canovas et al. (2005). LAB isolates were cultured in MRSB medium and incubated for $24 \mathrm{~h}$ at $37{ }^{\circ} \mathrm{C}$. The isolate was centrifuged for $10 \mathrm{~min}$ at $4500 \mathrm{rpm}$ to obtain the biomass and then homogenized with the sterile skim milk $(20 \% \mathrm{w} / \mathrm{v})$. The operating procedures of the spray dryer are as follows: the outlet temperature of $68{ }^{\circ} \mathrm{C}$, air temperature of $110^{\circ} \mathrm{C}$, and pump velocity 3 . The population of $\mathrm{LAB}$ before and after spray drying were count with total plate count (TPC) method on MRS agar medium. Microencapsulated culture of $S$. cerevisiae B-18 was prepared by drying method (Leja et al., 2009). A total of $10 \%(\mathrm{v} / \mathrm{v})$ of yeast isolates were cultured on CYG broth medium and incubated for $24 \mathrm{~h}$ at $30^{\circ} \mathrm{C}$ then tapioca flour was added as a matrix $(50 \%, \mathrm{w} / \mathrm{v})$. The incubation yeast cultures were homogeneously mixed into tapioca and dried at $50{ }^{\circ} \mathrm{C}$ for 30 hours. The population of yeast before and after before and after spray drying were calculated with TPC method on CYG agar medium.

Dry culture of probiotic was prepare to 
protect the probiotic against adverse conditions during processing, storage and along the gastrointestinal tract (Iravani et al., 2015). The use of drying methods using ovens is related to easy and economical material preparation, and the results of the products produced are stable (Corcoran et al., 2004). Population of dry culture LAB used for the treatment was $7.8 \times 10^{7} \mathrm{cfu} / \mathrm{g}$ while yeast probiotic was $5.3 \times 10^{6} \mathrm{cfu} / \mathrm{g}$. The mixture of these two probiotics were performed by mixing each probiotic in $1: 1$ part $(\mathrm{w} / \mathrm{w})$ to obtain final population around $10^{6} \mathrm{cfu} / \mathrm{g}$ as probiotic culture requirement.

\section{Experimental Site}

Care and management of the quails followed the international practices for animal use and care (Huss et al., 2008) and carried out in a closed house enclosure equipped with several supporting devices such as cooling pad, exhaust fan, thermo hygrometer/temptron, 60-W wolfram light bulb, and gas brooder. The experimental house was cleaned and disinfected before the arrival of birds. This study had fulfilled the ethical clearance requirement from Integrated Research and Testing Laboratory of Gadjah Mada University (No. 00136/04/LPPT/XI/2017).

\section{Experimental Birds and Design}

This study used 600 quail laying age of 21 days during 135 days (initial body weight 101.35 $\pm 1.64 \mathrm{~g}$ ) of a experiment period. Access for feed and drinking water were ad libitum. The trial design was using Completely Randomized Design (CRD) consist of 5 treatments and 6 replicates, each consisted of 20 quails with the treatments: A $=$ negative control (basal diet without probiotic), $\mathrm{B}=1 \%$ of $L$. plantarum AKK-30 $\left(10^{7} \mathrm{cfu} / \mathrm{g}\right), \mathrm{C}=$ $1 \%$ S. cerevisiae B-18 $\left(10^{6} \mathrm{cfu} / \mathrm{g}\right), \mathrm{D}=1 \%$ of a probiotic consortium, $\mathrm{E}=$ positive control (commercial probiotic). All probiotics were administered through drinking water. Each treatment additive was dissolved in $300 \mathrm{~mL}$ of drinking water then distributed $50 \mathrm{~mL}$ for each replicate. Lokapirnasari et al. (2018) reported that probiotics supplied to birds in drinking water is more effective than those in diet.

During 21-31 days of age, quail was given grower feed (formulation attached) in the form of crumble feed ( $5 \mathrm{~mm}$ of particle size), and entering 32-34 days of age, grower and layer feed mixed with composition as follows: Age of 32 days ( $75 \%$ grower feed $+25 \%$ layer feed); Age of 33 days ( $50 \%$ grower feed $+50 \%$ layer feed); Age of 34 days ( $25 \%$ grower feed $+75 \%$ layer feed), and since 35 days of age quails consumed layer feed (formulation attached). Basal diet of quail grower and layer were formulated to meet or exceed NRC (1994) recommendations. Vaccination programs include AI vaccinations (via injection) and ND (via drops) at 21-25 days, and booster ND (via drops) at 4 months of age. Three days before and after vaccination, quails were given with antistress (dose $1 \mathrm{~g} / \mathrm{L}$ of drinking water).

\section{Proximate Analysis of Formulated Feed}

Formulated feeds (Table 1) were then analyzed using AgraQuant ${ }^{\circledR}$ Total Aflatoxin Assay (Romer Labs, Singapore) for aflatoxin content assay by microplate reader (Thermo Scientific Multiscan Go) and nutrient content including moisture content, ash, crude fat, crude protein, crude fiber according to AOAC method (1990), energy, phosphorus, and calcium mineral. The moisture content was analyzed by drying the feed sample overnight at $105^{\circ} \mathrm{C}$. The ash content was measured by burning samples at $500{ }^{\circ} \mathrm{C}$ overnight. The crude protein (CP) content was determined based on the Kjeldahl method. The fat/lipid content was determined using a soxhlet extraction process which was performed with a soxhlet apparatus. The gross energy content was measured with bomb calorimeter. Metabolizable energy (ME) was calculated by multiplied the gross energy by 0.7. Barzegar et al. (2020) stated that the proportion of gross energy lost via excreta is approximately $30 \%$, hence, about $70 \%$ of the gross energy of a common diet fed to poultry is metabolized.

\section{Biochemical Analysis of Blood}

Meat and other tissues are taken after the birds decapitated. Blood sampling was performed once at the end of the trial period from 30 quails. The decapitation method was performed by taking the blood sample and inserted into microtube which has been given anticoagulant Ethylenediaminetetraacetic acid (EDTA). Analysis of blood samples to measure blood cholesterol levels by enzymatic colorimetric cholesterol-oxidase (CHOD-PAP) method, while blood triglyceride level by an enzymatic colorimetric using method of enzymatic colorimetric glycerol-3-phosphate-oxidase (GPOPAP). 


\begin{tabular}{lcc}
\hline \multirow{2}{*}{ Raw Material } & \multicolumn{2}{c}{ Percentage (\%) } \\
\cline { 2 - 3 } Corn & Grower feed & Layer feed \\
Soybean meal (SBM) & 51.7 & 55.1 \\
Meat bone meal (MBM) & 38.8 & 30.5 \\
Crude palm oil (CPO) & 4.00 & 4.00 \\
Premix & 1.60 & 2.80 \\
Dicalcium phosphate (DCP) & 0.10 & 0.10 \\
Salt & 0.30 & 0.80 \\
Limestone & 0.20 & 0.10 \\
L-lys & 1.50 & 5.70 \\
DL-meth & 1.00 & 0.70 \\
Total & 0.80 & 0.20 \\
Nutrient content & 100.00 & 100.00 \\
Moisture (\%) & Grower Feed & Layer Feed \\
Crude protein (\%) & 11.6 & 10.6 \\
Crude fat (\%) & 23.3 & 21.3 \\
Crude fiber (\%) & 5.07 & 7.16 \\
Ash (\%) & 3.17 & 4.15 \\
Calcium (\%) & 10.2 & 13.4 \\
Phosphorus (\%) & 5.46 & 3.38 \\
Total aflatoxin (ppb) & 0.76 & 0.76 \\
Gross energy (kcal/kg) & 29.2 & 22.1 \\
Metabolizable energy (kcal/kg) & 4,357 & 4,391 \\
\hline
\end{tabular}

\section{Analysis of Egg Quality and Cholesterol}

Egg samples (1 egg per experimental unit) were taken at the end of the experimental period. The analysis includes the physical properties of the egg (egg length, egg width, egg volume, egg weight, egg width, egg index, The Haugh Unit (HU), albumen height, albumen width, albumen length, albumen weight, albumen index, yolk color, yolk height, yolk diameter, yolk weight, and yolk index). Egg yolk cholesterol was analyzed based on Plummer method (1987). A total of 0.2 $\mathrm{mL}$ samples of egg yolks were mixed with $10 \mathrm{~mL}$ acetone and ethanol (1:1), the solution was boiled for 15 minutes in a water bath. Then it was sonicated for 5 minutes and centrifuged with 3000 rpm rotation speed for 15 minutes. The supernatant is taken and transferred to a tube and evaporated in the water bath until it runs out. The sample residue was added by $2 \mathrm{~mL}$ of chloroform and $2 \mathrm{~mL}$ of a mixture of concentrated sulfuric acid and anhydrous acetate (1:1) and then homogenized until the color turns into blue. The absorbance results were detected at a wavelength of $680 \mathrm{~nm}$.

\section{Analysis of Meat Quality and Cholesterol}

Breast meat samples (1 sample per experimental unit) were taken at the end of the trial period. The analysis includes the physical properties of meat $\mathrm{pH}$ (Soeparno, 2005), cooking 
loss (Nikmaram et al., 2011), water holding capacity (Hamm, 1960), and tenderness (Soeparno, 2005). Nutrient content of meat was analyzed including moisture content, ash, crude fiber, protein, and fat based on AOAC (1990). Meat cholesterol content was analyzed based on Plumer method (1987) as describe previously.

\section{Performance of Egg Production}

Quail day production (QDP) is measured by dividing the total number of eggs produced per day per experimental unit by the number of quail alive per experimental unit and then multiplied by $100 \%$. The average egg weight is measured per bird. Feed consumption was calculated per experimental unit. The feed conversion ratio (FCR) was measured as the amount of feed consumed per experimental unit divided by average of egg mass per experimental unit and and feed efficiency calculated by weight of the eggs produced compared to the feed intake (Lokapirnasari et al., 2017). Egg mass is calculated as laying rate per experimental unit divided by average egg weight per experimental unit (Attia et al., 2013).

\section{Data Analysis}

All analyses were determined at least triplicate. The performance data were evaluated using one-way analysis of variance (ANOVA). The significant difference between treatment means was analyzed using Duncan's Range Test (Gomez and Gomez, 2007). Statistical analysis was performed with Costat software (CoHort Software, 2008). The analysis results are performed as means and standard deviation (SD).

\section{RESULTS AND DISCUSSIONS}

\section{Probiotics Viability and Potency in Cholesterol-Lowering}

Viability of L. plantarum AKK-30 and $S$. cerevisiae B-18 as a probiotic on quail performance was visualized in Table 2 . Viability of L. plantarum AKK-30 after spray drying process was $0.8 \%$, while the viability of $S$. cerevisiae B-18 with the oven drying process was $2.8 \%$. Both drying methods decreased the number of colonies of both isolates by 2 logs of cycles. Probiotic bacterial cells can be protected by microencapsulation processes against adverse conditions during processing, storage and along the gastrointestinal tract (Iravani et al., 2015).

The drying process in yeasts used an additional matrix of tapioca starch that served to shield the yeast cells during the drying process because the cell could be damaged by heat stress (Leja et al., 2009). This skim milk was used as a filler in the process of making a dry culture of $L$. plantarum AKK-30 because the sugar content in the skim was good to support the growth of LAB strain which generally has lactase enzyme which is capable of converting lactose to glucose. Skim milk is capable of preventing cellular injury by creating a structure easy to rehydrate after drying, stabilizing the cell membrane, and protecting the cells as it contains proteins that provide a protective coating to the cells (Silva et al., 2011). Tapioca as a filler in the process of making yeast dry culture aims to make $S$. cerevisiae B-18 grow well in tapioca encapsulation. The use of drying methods using ovens is related to easy and economical material preparation, and the results of the products produced are stable (Corcoran et al., 2004). During spray drying, the cell undergoes thermal inactivation and dehydration simultaneously. The inlet and outlet temperatures in the spray drying process could be one of the main causes of cell damage or death so most of the microbes, generally optimally mesophilic LAB colonies grown at $40^{\circ} \mathrm{C}$ could not survive at elevated temperatures.

In the previous in vitro studies, we reported that both probiotics performed cholesterollowering activities (Julendra et al., 2017; Istiqomah et al., 2018). The cholesterol-lowering activities of $L$. plantarum AKK-30 and $S$. cerevisiae B-18 were $17.4 \%$ and $51.8 \%$ respectively (Table 2). These findings were supported by others studies revealed that $L$. plantarum and $S$. cerevisiae have the hypocholesterol activity in mice (Saikia et al., 2018; Nallala and Jeevaratnam, 2019).

\section{Blood Biochemical Profiles}

The blood biochemical profiles in Figure 1 showed that administration of $S$. cerevisiae B-18 (C treatment) decreased $(\mathrm{P}<0.05)$ the blood cholesterol levels compared to control, whereas no difference results was found in triglycerides, LDL, and blood HDL level when probiotic added into drinking water $(\mathrm{P}>0.05)$. Low cholesterol of blood serum in $\mathrm{C}$ treatment might be associated with the hypocholesterolemic activity of $S$. cerevisiae. Probiotic able to assimilate or degrade the cholesterol to bile acids followed by deconjugation to prevent re-synthesis (El-Kelawy and Elnagar, 2016). The in vitro activity of 
cholesterol-lowering was caused by the acceptance of cholesterol in growing yeast cells. The binding of bile acids by $\beta$-glucans in the human intestine were able to eliminate in bile acid pool and improved cholesterol breakdown. In previous studies (Julendra et al., 2017; Istiqomah et al., 2018) found that viability and cholesterol lowering activity of $S$. cerevisiae B-18 was higher than L. plantarum AKK-30.

Yalçın et al. (2010) reported that supplementation of $S$. cerevisiae in diet reduced cholesterol content in blood and egg yolk of laying hens. Probiotic might stimulate the activity of lipoprotein HDL to reduce accumulation of cholesterol in blood and tissue (Nallala and Jeevaratnam, 2019). Moreover, Saikia et al. (2018) revealed that $S$. cerevisiae ARDMC1 showed potential probiotic characteristics and exhibited in vitro cholesterol assimilation properties. For comparison, Hussein and Selim (2018) stated that broiler chickens fed $0.5 \%$ dried yeast $S$. cerevisiae, $0.5 \%$ mix-strain probiotic ( $B$. subtilis, L. acidophilus, and A. oryzae), and its mixture had lower cholesterol and total lipids than the control.

In contrary, other study was in disagreement with our finding that probiotic LAB supplementation in chicken significantly $(\mathrm{P}<0.05)$

Table 2. Viability of Isolates Before and After Drying Process

\begin{tabular}{lccccc}
\hline \multirow{2}{*}{ Isolate } & $\begin{array}{c}\text { Before Carrier } \\
\text { Addition }\end{array}$ & $\begin{array}{c}\text { After Carrier } \\
\text { Addition }\end{array}$ & \multicolumn{2}{c}{ After Drying } & Cholesterol- \\
\cline { 5 - 6 } & $(\mathrm{cfu} / \mathrm{g})$ & $(\mathrm{cfu} / \mathrm{g})$ & Colony $(\mathrm{cfu} / \mathrm{g})$ & Viability $(\%)$ & $\begin{array}{c}\text { lowering } \\
(\%)\end{array}$ \\
\hline L. plantarum AKK-30 & $9.4 \times 10^{9}$ & $8.8 \times 10^{9}$ & $7.8 \times 10^{7}$ & 0.8 & $17.4^{1}$ \\
S. cerevisiae B-18 & $1.9 \times 10^{8}$ & $2.0 \times 10^{8}$ & $5.3 \times 10^{6}$ & 2.8 & $51.8^{2}$ \\
\hline
\end{tabular}

${ }_{1}^{1}$ Value denotes relative activity for reducing cholesterol as previously reported by Julendra et al. (2017)

${ }^{2}$ Assimilating activity as previously reported by Istiqomah et al. (2018)

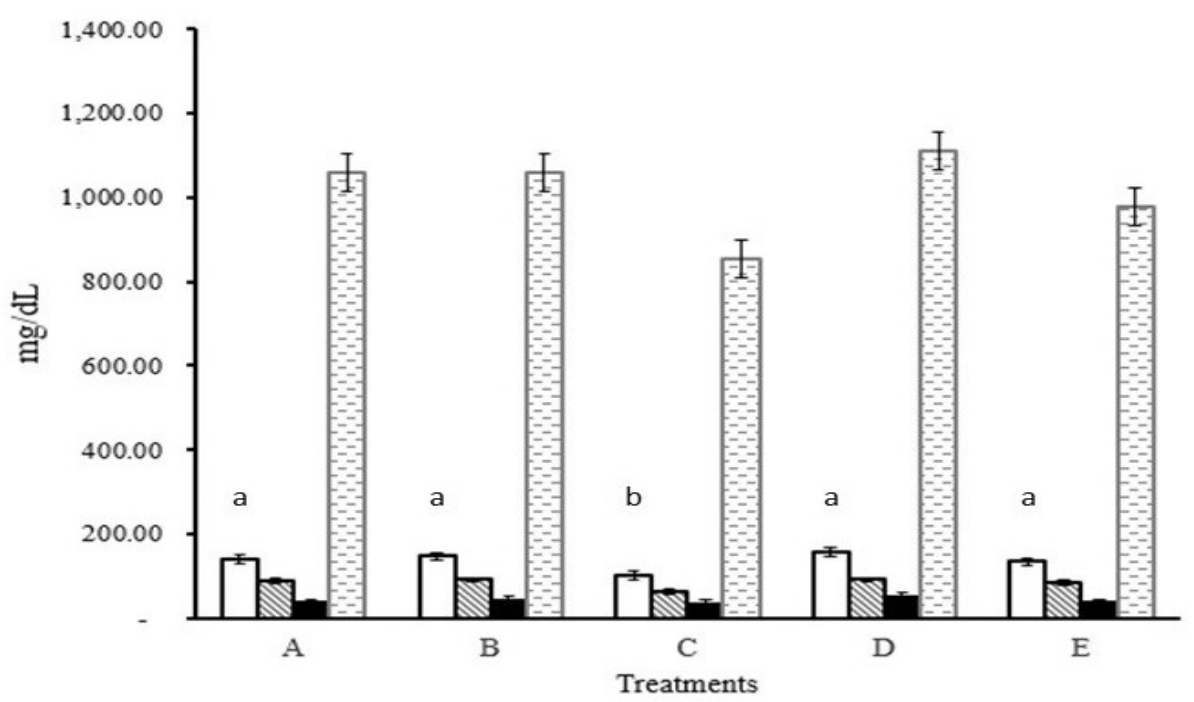

Figure 1. The Content of Blood Cholesterol, LDL, HDL, and Triglycerides in Various Treatments. A: negative control (without probiotic); B: 1\% of L. plantarum AKK-30; C: 1\% of S. cerevisiae B-18; D: $1 \%$ of a probiotic consortium $(\mathrm{B}+\mathrm{C}) ; \mathrm{E}$ : positive control (commercial probiotics).
$\square$ Blood cholesterol
बLDL
- HDL
$\square$ Triglyseride 
depressed serum total cholesterol levels than control (Cenesiz et al., 2008). Lokapirnasari et al. (2018) stated that feed additive contains $L$. rhamnosus and $L$. casei could increase egg quality by reducing LDL, cholesterol, increasing HDL and total protein. Kalafova et al. (2018) reported that adults quails fed probiotic (B. subtilis, $10^{7}$ cfu/g and L. paracasei, $10^{7} \mathrm{cfu} / \mathrm{g}$ ) did not affect total cholesterol and tryglicerides.

\section{Cholesterol Content in Egg and Meat}

Egg yolk cholesterol content in A or $\mathrm{C}$ treatment was lower $(\mathrm{P}<0.05)$ than others treatments, however it did not differ with $\mathrm{E}$ treatment as described in Figure 2. The low level of serum total cholesterol in S. cerevisiae B-18 treatment leads to a decrease in yolk cholesterol content too. Saccharomyces cells excreted oligosaccharides that increase number and colonization of lactobacilli. The Lactobacilli reduce the bile acids (cholic and deoxycholic) recycling, and adsorb cholesterol that leading to reduction of its absorption from the intestine, with subsequent lowering its level in blood, meat, and eggs (Hassanein and Soliman, 2010). Kalsum et al. (2012) reported that single probiotic of $L$. fermentum lowered cholesterol content in egg yolk. The reduction effect of the cholesterol content of the eggs by more than $26 \%$ was reported by using Kluyveromyces marxianus M3 strain yeast (Zhong et al., 2016). Khalifa and Noseer (2019) reported that quail fed on combination of probiotics (L. acidophilus, $10^{6} \mathrm{cfu}$ and $S$. cerevisiae $10^{2} \mathrm{cfu}$ ) with ginger produced the lowest yolk cholesterol $(10.6 \mathrm{mg} / \mathrm{g})$ compared to control group $(14.1 \mathrm{mg} / \mathrm{g})$.

Administration of probiotics did not affect the meat cholesterol content $(\mathrm{P}>0.5)$. Other studies about this parameter on quail are still limited. In contrary with this study, Istiqomah et al. (2013) reported that broilers fed probiotic (multi culture, $10^{12} \mathrm{cfu} / \mathrm{g}$ ) produced meat with lower cholesterol content $(58.40 \mathrm{mg} / 100 \mathrm{~g})$ than control $(85.74 \mathrm{mg} / 100 \mathrm{~g})$. Trembecká et al. (2020) also stated that the breast meat of chickens fed with propolis and probiotic (L. fermentum) had the lowest cholesterol content $(77.94 \mathrm{mg} / 100 \mathrm{~g})$ compare than other treatments (87.06 and 90.14 $\mathrm{mg} / 100 \mathrm{~g})$.

\section{Probiotics Effect on Quails Performance}

Dietary effect of probiotics during the grower period (3-5 weeks of age) was shown in Table 3, while the layer period (6-20 weeks of age) was shown in Table 4. Data in Table 3 indicated that administration of probiotic on the grower period did not affect $(\mathrm{P}>0.05) \mathrm{BWG}$, feed intake, feed efficiency, and mortality. Table 4 showed that administration of $1 \%$ single probiotic and its consortium did not affect the production performance (HDP, FCR, feed efficiency or egg uniformity).

This finding showed that administration of $1 \%$ single probiotic, its consortium, and commercial probiotic did not affect growth performance of quail in growing and laying

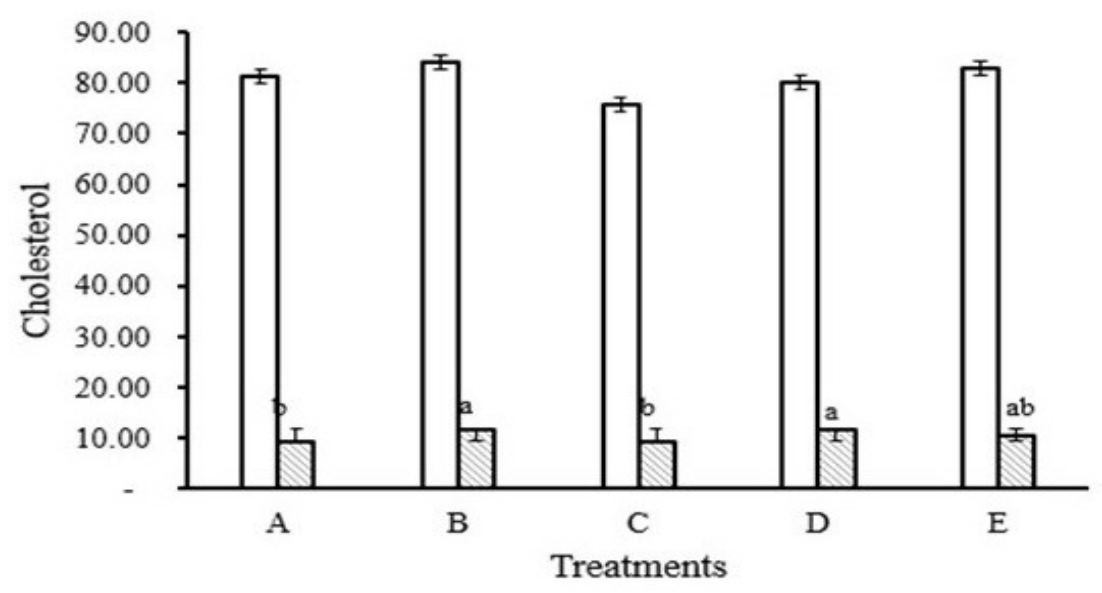

Figure 2. The Yolk and Meat Cholesterol Content in Various Probiotic Treatments. A: negative control (without probiotic); B: $1 \%$ of $L$. plantarum AKK-30; C: $1 \%$ of S. cerevisiae B-18; D: $1 \%$ of a probiotic consortium $(\mathrm{B}+\mathrm{C})$; E: positive control (commercial probiotics)

$\square$ Meat cholesterol (mg/100 g) $\otimes$ Yolk cholesterol (mg/g) 
period $(\mathrm{P}>0.05)$ nor production performance (HDP, FCR, feed efficiency, egg weight nor egg mass). On the other hand, another finding was in disagreement with our findings. Hosseini (2011) reported a significant improvement in body weight, weight gain, and feed consumption throughout the experiment. Manafi et al. (2016) stated that the dietary addition of $B$. subtilis and BMD increased egg production and egg weight. Siadati et al. (2018) reported that administration of native Lactobacillus strains (50 g/ton) had no significant effect on egg weight and feed intake, whereas improved feed conversion ratio (FCR), egg production, and egg mass during the laying period. Supplementation of probiotic-enzyme did not effect on the body weight gain, egg mass, feed intake, feed conversion, cracked egg yield, specific gravity and shell strength (Olgun and Y1ld1z, 2014). Lack effect of probiotic on feed intake, feed efficiency might be due to the several factors such as differences in the chemical composition of the ingredients of the diet, differences in the levels (percentage), adaptation of probiotic, and the selectivity of the microflora and stress factors (Ayasan et al., 2006; Guclu, 2011). The repeated measures analysis (Figure 3) indicated a significant effect of time on egg production $(\mathrm{P}<0.05)$.

Mechanism of enhancing probiotic effects on quails performance presumably correlated with activity of digestive enzymes. Abdel-Moneim et al. (2020) revealed that dietary probiotic involves in enhancing of protease, lipase, and amylase activities in quails. The increased egg production by both probiotic due to the elongated small and large intestinal lengths as well as the their suppressing effects on undesirable bacteria and stimulating effects on the growth and/or activity of beneficial bacteria and pressing pathogenic bacteria in the intestines which increase absorptive capacity (Lokapirnasari et al., 2017).

\section{Quality of Quail Eggs}

Administration of probiotic treatments increased the diameter of egg yolk $(\mathrm{P}<0.05)$ compared to control (Table 5). Administration of S. cerevisiae B-18 (C) and commercial probiotic (E) resulted in the highest albumen length $(\mathrm{P}<0.05)$ than other treatments. A consortium of L. plantarum AKK-30 and S. cerevisiae B-18 (D) treatment resulted the highest dry matter and fat content of egg $(\mathrm{P}<0.05)$ and the lowest protein content $(\mathrm{P}<0.05)$ than other treatments, whereas commercial probiotic (E) produced the lowest fat content $(\mathrm{P}<0.05)$ among others.

The high reduction of egg fat content observed in $S$. cerevisiae (C treatment) or commercial probiotics (E treatment) possibly associated with the role of $S$. cerevisiae metabolic activity. Mechanism of reduction by yeasts may associated with b-glucans in yeast cell has capability to bind to bile acids in the intestine, resulting in a decrease in bile acid pool and enhanced cholesterol breakdown. These enhance production of short-chain fatty acids and reduce synthesis of hepatic cholesterol (Saikia et al.,

Table 3. Performance of Quail on Grower Period (3-5 Weeks of Age)

\begin{tabular}{lrrrrr}
\hline \multirow{2}{*}{ Parameter } & \multicolumn{5}{c}{ Treatments } \\
\cline { 2 - 6 } & \multicolumn{1}{c}{$\mathrm{A}$} & \multicolumn{1}{c}{$\mathrm{B}$} & $\mathrm{C}$ & $\mathrm{D}$ & $\mathrm{E}$ \\
\hline Initial body weight (g/bird) & $102.1 \pm 2.87^{\mathrm{a}}$ & $101.9 \pm 2.57^{\mathrm{a}}$ & $103.1 \pm 1.73^{\mathrm{a}}$ & $100.9 \pm 1.19^{\mathrm{ab}}$ & $98.8 \pm 2.56^{\mathrm{b}}$ \\
Final body weight (g/bird) & $180.5 \pm 3.94$ & $178.5 \pm 4.20$ & $182.9 \pm 3.88$ & $177.6 \pm 5.48$ & $176.9 \pm 7.71$ \\
Body weight gain (g/bird) & $5.60 \pm 0.15$ & $5.47 \pm 0.27$ & $5.70 \pm 0.25$ & $5.48 \pm 0.36$ & $5.58 \pm 0.43$ \\
Feed consumption (g/bird) & $20.0 \pm 0.99$ & $19.9 \pm 0.58$ & $20.5 \pm 0.24$ & $19.7 \pm 0.36$ & $20.5 \pm 0.96$ \\
FCR & $3.57 \pm 0.17$ & $3.65 \pm 0.19$ & $3.63 \pm 0.09$ & $3.67 \pm 0.24$ & $3.68 \pm 0.26$ \\
Feed efficiency & $28.0 \pm 1.35$ & $27.5 \pm 1.33$ & $27.6 \pm 0.68$ & $27.4 \pm 1.79$ & $27.3 \pm 1.87$ \\
Livability (\%) & $100.0 \pm 0.00$ & $100.0 \pm 0.00$ & $100.0 \pm 0.00$ & $100.0 \pm 0.00$ & $99.2 \pm 2.04$ \\
\hline
\end{tabular}

Means in the same row with different superscript differ significantly $(\mathrm{P}<0.05)$. A: negative control (without probiotic); B: $1 \%$ of $L$. plantarum AKK-30; C: $1 \%$ of $S$. cerevisiae B-18; D: $1 \%$ of a probiotic consortium $(\mathrm{B}+\mathrm{C})$; E: positive control (commercial probiotics) 
Table 4. Performance of Quail on Layer Period (6-20 Weeks of Age)

\begin{tabular}{lccccc}
\hline \multirow{2}{*}{ Parameter } & \multicolumn{5}{c}{ Treatments } \\
\cline { 2 - 6 } & $\mathrm{A}$ & $\mathrm{B}$ & $\mathrm{C}$ & $\mathrm{D}$ & $\mathrm{E}$ \\
\hline BW on 6 weeks (g/bird) & $212.6 \pm 5.13$ & $211.1 \pm 5.91$ & $214.7 \pm 2.78$ & $212.2 \pm 4.92$ & $209.6 \pm 3.57$ \\
BW on 20 weeks (g/bird) & $243.0 \pm 5.21$ & $245.5 \pm 2.87$ & $242.7 \pm 3.35$ & $244.1 \pm 1.56$ & $241.9 \pm 7.04$ \\
BWG (g/bird/day) & $30.4 \pm 2.71^{\mathrm{ab}}$ & $34.4 \pm 5.01^{\mathrm{a}}$ & $28.0 \pm 3.87^{\mathrm{b}}$ & $31.8 \pm 4.98^{\mathrm{ab}}$ & $32.3 \pm 4.84^{\mathrm{ab}}$ \\
Feed consumption (g/bird/day) & $26.6 \pm 1.15$ & $26.9 \pm 1.01$ & $27.1 \pm 1.22$ & $26.2 \pm 0.65$ & $26.7 \pm 0.55$ \\
FCR & $2.69 \pm 0.14$ & $2.72 \pm 0.14$ & $2.66 \pm 0.05$ & $2.71 \pm 0.07$ & $2.75 \pm 0.08$ \\
Feed efficiency (\%) & $37.3 \pm 1.91$ & $36.9 \pm 1.93$ & $37.6 \pm 0.73$ & $37.0 \pm 1.01$ & $36.4 \pm 1.03$ \\
Livability (\%) & $97.5 \pm 2.74$ & $98.3 \pm 2.58$ & $95.8 \pm 3.76$ & $98.3 \pm 2.58$ & $98.3 \pm 2.58$ \\
HDP (\%) & $81.2 \pm 5.21$ & $78.8 \pm 3.41$ & $83.1 \pm 3.20$ & $80.0 \pm 2.06$ & $80.0 \pm 2.31$ \\
Egg weight (g/egg) & $12.2 \pm 0.28$ & $12.4 \pm 0.58$ & $12.3 \pm 0.19$ & $12.1 \pm 0.27$ & $12.2 \pm 0.18$ \\
Egg mass (g/bird/day) & $9.92 \pm 0.71$ & $9.10 \pm 0.56$ & $10.2 \pm 0.46$ & $9.67 \pm 0.19$ & $9.74 \pm 0.24$ \\
\hline
\end{tabular}

Means in the same row with different superscript differ significantly $(\mathrm{P}<0.05)$. A: negative control (without probiotic); B: $1 \%$ of $L$. plantarum AKK-30; C: $1 \%$ of $S$. cerevisiae B-18; D: $1 \%$ of a probiotic consortium $(\mathrm{B}+\mathrm{C})$; E: positive control (commercial probiotics)

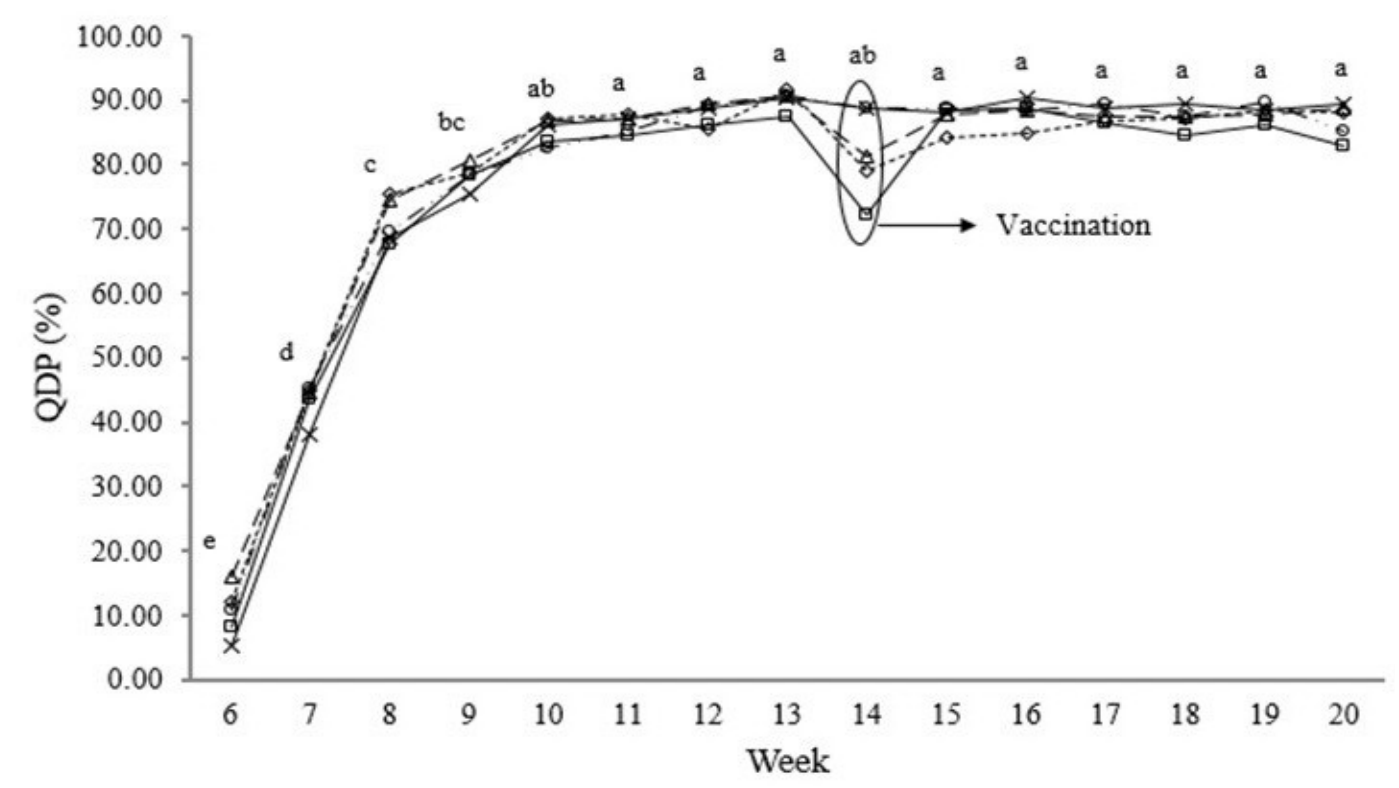

Figure 3. Quail Day Production during 15 Weeks of Observation with Various Treatments. A: negative control (without probiotic); B: $1 \%$ of $L$. plantarum AKK-30; C: $1 \%$ of $S$. cerevisiae B-18; D: $1 \%$ of a probiotic consortium $(\mathrm{B}+\mathrm{C})$; $\mathrm{E}$ : positive control (commercial probiotics)

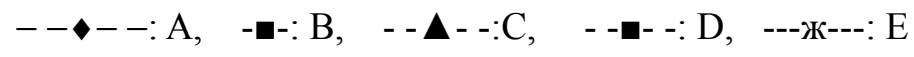


Table 5. The Physical Quality and Nutrient of Quail Eggs in the End of Experiment Performance of Quail on Layer Period (6-20 Weeks of Age)

\begin{tabular}{lccccc}
\hline \multirow{2}{*}{ Parameter } & \multicolumn{5}{c}{ Treatments } \\
\cline { 2 - 6 } & $\mathrm{A}$ & $\mathrm{B}$ & $\mathrm{C}$ & $\mathrm{D}$ & $\mathrm{E}$ \\
\hline Egg length (cm) & $3.35 \pm 0.00$ & $3.35 \pm 0.10$ & $3.35 \pm 0.17$ & $3.33 \pm 0.06$ & $3.39 \pm 0.15$ \\
Egg width (cm) & $2.41 \pm 0.06$ & $2.46 \pm 0.02$ & $2.36 \pm 0.10$ & $2.37 \pm 0.04$ & $2.41 \pm 0.01$ \\
Egg volume & $11.8 \pm 0.29$ & $12.2 \pm 0.29$ & $11.7 \pm 0.58$ & $11.8 \pm 0.29$ & $12.3 \pm 0.58$ \\
Egg weigth (g) & $1.30 \pm 0.03$ & $1.40 \pm 0.14$ & $1.22 \pm 0.22$ & $1.25 \pm 0.26$ & $1.33 \pm 0.11$ \\
Egg width (cm) & $0.20 \pm 0.00$ & $0.22 \pm 0.01$ & $0.20 \pm 0.02$ & $0.20 \pm 0.02$ & $0.22 \pm 0.03$ \\
Egg index & $71.8 \pm 1.85$ & $73.4 \pm 1.92$ & $70.5 \pm 1.74$ & $71.3 \pm 2.29$ & $71.0 \pm 3.08$ \\
Haugh Unit & $84.1 \pm 6.95$ & $83.0 \pm 3.15$ & $85.1 \pm 7.98$ & $84.4 \pm 6.32$ & $87.0 \pm 2.58$ \\
Albumen height (cm) & $4.02 \pm 0.54$ & $3.64 \pm 0.54$ & $3.94 \pm 1.35$ & $3.55 \pm 0.78$ & $4.28 \pm 0.40$ \\
Albumen length (cm) & $4.36 \pm 0.17^{\mathrm{ab}}$ & $4.00 \pm 0.42^{\mathrm{b}}$ & $4.94 \pm 0.40^{\mathrm{a}}$ & $4.31 \pm 0.44^{\mathrm{ab}}$ & $4.87 \pm 0.41^{\mathrm{a}}$ \\
Albumen width (cm) & $2.91 \pm 0.39$ & $3.02 \pm 0.44$ & $3.13 \pm 0.31$ & $2.81 \pm 0.04$ & $3.03 \pm 0.09$ \\
Albumen weight (g) & $6.70 \pm 0.56$ & $7.37 \pm 0.08$ & $6.72 \pm 0.80$ & $6.83 \pm 0.55$ & $7.10 \pm 0.09$ \\
Albumen index & $0.11 \pm 0.02$ & $0.10 \pm 0.01$ & $0.10 \pm 0.04$ & $0.10 \pm 0.02$ & $0.11 \pm 0.01$ \\
Yolk color & $8.00 \pm 0.00$ & $7.67 \pm 0.58$ & $7.67 \pm 0.58$ & $7.67 \pm 0.58$ & $8.00 \pm 0.00$ \\
Yolk height (cm) & $11.2 \pm 0.36$ & $10.6 \pm 0.17$ & $11.4 \pm 1.06$ & $11.0 \pm 0.13$ & $10.6 \pm 0.49$ \\
Yolk diameter (cm) & $2.13 \pm 0.03^{\mathrm{c}}$ & $2.34 \pm 0.01^{\mathrm{b}}$ & $2.32 \pm 0.05^{\mathrm{b}}$ & $2.31 \pm 0.08^{\mathrm{b}}$ & $2.45 \pm 0.06^{\mathrm{a}}$ \\
Yolk weight (g) & $3.41 \pm 2.73$ & $3.75 \pm 0.25$ & $3.78 \pm 0.47$ & $3.61 \pm 0.19$ & $3.83 \pm 0.22$ \\
Yolk index & $0.52 \pm 0.02^{\mathrm{a}}$ & $0.45 \pm 0.01^{\mathrm{bc}}$ & $0.49 \pm 0.04^{\mathrm{ab}}$ & $0.48 \pm 0.02^{\mathrm{bc}}$ & $0.43 \pm 0.02^{\mathrm{c}}$ \\
Dry matter (\%) & $27.4 \pm 0.81^{\mathrm{ab}}$ & $27.2 \pm 1.54^{\mathrm{b}}$ & $27.0 \pm 1.07^{\mathrm{b}}$ & $28.8 \pm 1.32^{\mathrm{a}}$ & $26.4 \pm 1.23^{\mathrm{b}}$ \\
Ash (\%) & $3.86 \pm 0.44$ & $3.69 \pm 0.29$ & $3.67 \pm 0.22$ & $3.84 \pm 0.31$ & $3.88 \pm 0.17$ \\
Fiber (\%) & $15.0 \pm 4.72$ & $17.0 \pm 2.88$ & $12.2 \pm 1.44$ & $16.2 \pm 3.08$ & $14.1 \pm 5.07$ \\
Protein (\%) & $43.3 \pm 1.97^{\mathrm{bc}}$ & $43.5 \pm 3.34^{\mathrm{bc}}$ & $45.9 \pm 2.15^{\mathrm{ab}}$ & $41.4 \pm 3.83^{\mathrm{c}}$ & $47.8 \pm 3.04^{\mathrm{a}}$ \\
Fat (\%) & $12.0 \pm 0.68^{\mathrm{ab}}$ & $12.2 \pm 0.94^{\mathrm{ab}}$ & $11.6 \pm 2.04^{\mathrm{ab}}$ & $12.8 \pm 0.40^{\mathrm{a}}$ & $10.8 \pm 1.13^{\mathrm{b}}$ \\
\hline Mean in & & & & \\
\hline
\end{tabular}

Means in the same row with different superscript differ significantly $(\mathrm{P}<0.05)$. A: negative control (without probiotic); B: $1 \%$ of $L$. plantarum AKK-30; C: $1 \%$ of $S$. cerevisiae B-18; D: $1 \%$ of a probiotic consortium $(\mathrm{B}+\mathrm{C})$; E: positive control (commercial probiotics)

2018). Cholesterol-lowering effect was also reported in previous study that the assimilation activity of $S$. cerevisiae about $51.8 \%$ (Istiqomah et al., 2018).

Administration of probiotics did not affect several physical quality of egg i.e. length, width, volume, and index of egg, Haugh Unit (HU), the height, weight, and index of albumen, the color, height, and weight of yolk. However, it had significant effects on albumen length, yolk diameter and yolk index. This finding was accordance to Kalsum et al. (2012) who reported that administration of $L$. fermentum did not influence egg quality parameters (haugh unit, \% 
egg albumen, \% egg yolk and egg shell thickness) and egg weight. Manafi et al. (2016) stated that the dietary inclusion of B. subtilis and BMD were not effecting the eggshell characteristics i.e., thickness, breaking strength, percentages, and also haugh unit. Zhong et al. (2016) stated that supplementation of $0.3 \%$ yeast Kluyveromyces marxianus M3 strain on laying hen diet resulted in significant differences in the eggs nutrient composition (increase protein, crude fat level, and dry matter), weights, shell strength, albumen height, and haugh unit. Siadati et al. (2018) reported that probiotic treatments (Protexin, Primalac, and Lactobacillus strains) had significant positive effects $(\mathrm{P}<0.05)$ on the height of albumen, haugh unit, and internal quality unit (IQU), whereas eggshell, yolk weight, and egg albumen weight of the quails were not affected by the treatments $(\mathrm{P}>0.05)$.

\section{Meat Quality}

The consumers are concerned about meat quality especially lower fat content. To achieved this goal several ways are taken, one of them is by probiotic inclusion as a feed additive to poultry. Probiotic with a cholesterol-lowering activity that has bile-salt hydrolase (BSH) enzyme could deconjugates bile acids into glycine or taurine from the steroid portions and produces free bile salts (Tomaro-Duchesneau et al., 2014). Reproduced bile salts were not readily absorbed by the small intestine, therefore it was excreted in the excreta, and several bile acids that return to the liver became less. BSH activity was detected in several GI-related strains, representing several species of LAB such as Lactobacillus and Bifidobacterium derived from the digestive tract (Kumar et al., 2012). Julendra et al. (2017) stated that L. plantarum AKK-30 isolated from the gastrointestinal tract (colon) of Indonesia's native chicken has can lower cholesterol in vitro with the percentage of assimilated cholesterol $17.43 \%$.

In this study, Table 6 showed that probiotic administration decreased moisture content and fat, and increased the protein content of meat quail $(\mathrm{P}<0.05)$. Probiotic administration did not affect the ash and fiber content $(\mathrm{P}>0.05)$. Administration of $1 \%$ of $L$. plantarum (B treatment) increased meat protein content and depressed fat content $(\mathrm{P}<0.05)$ compared to control.

Physical properties of meat showed that the highest cooking loss and the lowest water holding was found on D treatment (consortium of $L$. plantarum and $S$. cerevisiae). Probiotic decreased acidic value $(\mathrm{pH})(\mathrm{P}<0.05)$. The tenderness of the meat quail administered probiotic were higher $(\mathrm{P}<0.05)$ than control, while administration of single probiotic $L$. plantarum did not affect the

Table 6. The Physical Quality and Nutrient of Quail Meat in the End of Experiment

\begin{tabular}{lccccc}
\hline \multirow{2}{*}{ Parameter } & \multicolumn{5}{c}{ Treatments } \\
\cline { 2 - 6 } & \multicolumn{1}{c}{$\mathrm{A}$} & $\mathrm{B}$ & $\mathrm{C}$ & $\mathrm{D}$ & $\mathrm{E}$ \\
\hline $\mathrm{pH}$ & $5.81 \pm 0.04^{\mathrm{a}}$ & $5.75 \pm 0.03^{\mathrm{a}}$ & $5.69 \pm 0.01^{\mathrm{c}}$ & $5.68 \pm 0.01^{\mathrm{c}}$ & $5.65 \pm 0.01^{\mathrm{d}}$ \\
Water holding capacity (\%) & $33.9 \pm 2.80^{\mathrm{a}}$ & $34.4 \pm 2.21^{\mathrm{a}}$ & $30.5 \pm 2.42^{\mathrm{b}}$ & $34.0 \pm 2.63^{\mathrm{a}}$ & $32.9 \pm 3.98^{\mathrm{ab}}$ \\
Cooking loss (\%) & $28.1 \pm 1.23^{\mathrm{b}}$ & $28.2 \pm 1.15^{\mathrm{b}}$ & $29.7 \pm 1.60^{\mathrm{ab}}$ & $31.0 \pm 1.54^{\mathrm{a}}$ & $29.3 \pm 1.80^{\mathrm{b}}$ \\
Tenderness (kg/cm $\left.{ }^{2}\right)$ & $2.38 \pm 0.15^{\mathrm{b}}$ & $2.38 \pm 0.18^{\mathrm{b}}$ & $2.53 \pm 0.14^{\mathrm{ab}}$ & $2.44 \pm 0.13^{\mathrm{ab}}$ & $2.61 \pm 0.19^{\mathrm{a}}$ \\
Moisture (\%) & $75.9 \pm 2.67^{\mathrm{a}}$ & $72.5 \pm 4.13^{\mathrm{ab}}$ & $71.9 \pm 2.52^{\mathrm{ab}}$ & $68.6 \pm 3.64^{\mathrm{b}}$ & $69.6 \pm 3.30^{\mathrm{b}}$ \\
Ash (\%) & $1.21 \pm 0.15$ & $1.37 \pm 0.21$ & $1.40 \pm 0.38$ & $1.32 \pm 0.37$ & $1.16 \pm 0.06$ \\
Fiber (\%) & $4.71 \pm 0.44$ & $3.86 \pm 1.22$ & $4.58 \pm 0.14$ & $3.82 \pm 0.22$ & $6.10 \pm 1.07$ \\
Protein (\%) & $19.5 \pm 1.86^{\mathrm{b}}$ & $21.5 \pm 1.29^{\mathrm{a}}$ & $20.8 \pm 0.35^{\mathrm{ab}}$ & $20.4 \pm 1.05^{\mathrm{ab}}$ & $20.4 \pm 1.29^{\mathrm{ab}}$ \\
Fat (\%) & $4.35 \pm 2.80^{\mathrm{ab}}$ & $2.01 \pm 0.84^{\mathrm{b}}$ & $3.14 \pm 1.17^{\mathrm{ab}}$ & $5.27 \pm 2.66^{\mathrm{a}}$ & $4.51 \pm 2.10^{\mathrm{ab}}$ \\
\hline
\end{tabular}

Means in the same row with different superscript differ significantly $(\mathrm{P}<0.05)$. A: negative control (without probiotic); B: $1 \%$ of L. plantarum AKK-30; C: $1 \%$ of $S$. cerevisiae B-18; D: $1 \%$ of a probiotic consortium $(\mathrm{B}+\mathrm{C})$; E: positive control (commercial probiotics) 
ash content of quail meat $(\mathrm{P}>0.05)$. Probiotic treatments decreased the $\mathrm{pH}$ acidic value and increased the cooking loss value, water holding capacity (WHC) compared to control $(\mathrm{P}<0.05)$. Abou-Kassem et al. (2020) reported that probiotics (B. toyonensis and Bifidobecterium bifidum) decreased cooking loss and increased WHC of quail meat. Soeparno (2005) revealed that the increased $\mathrm{pH}$ values of meat was associated with increased WHC and reduced cooking loss. Genchev et al. (2008) reported that $\mathrm{pH}$ values of Japanese quail meat around 6.17 with WHC value around $22.08 \%$. Acidic values of meat possibly influenced by glycogen content in muscles and glycogen stores which are highly dependent by the locomotors action and the disruption of stress factors while preparing slaughter. High $\mathrm{pH}$ of meat might affect a higher tenderness than meat with low $\mathrm{pH}$. Increase in $\mathrm{pH}$ of meat affect the holding capacity of water/meat juiciness (Soeparno, 2005). However, different result reported by Omar et al. (2019) who stated that the probiotic addition did not affect $(\mathrm{P}>0.05)$ the $\mathrm{pH}$ values of breast quails. Probiotic increased the $\mathrm{pH}$ value of breast muscles of chickens compared to control (Kim et al., 2017). Several factors might affect the WHC of meat such as during pre-mortem time duration likes grow time, diet and stresses and also post-mortem time duration likes chilling, aging and tumbling (Cheng and Sun, 2008).

Administration of $1 \%$ of L. plantarum (B) increased the protein content of meat and decreased the fat content and result was accordance with Ivanovic et al. (2012) who stated that probiotic $B$. cereus produced the lowest average of fat content $(2.33 \%)$ and the highest protein content $(23.63 \%)$ compared to control group of chickens $(3.32 \%$ and $23.38 \%$ respectively). The decreasing effect of crude fat content and increase of crude protein in chicken's breast meat by the inclusion of combination dried yeast and multi-strain probiotic in the diet was reported by Hussein and Selim (2018). Other paramaters related to the meat quality (moisture, ash and fiber) showing no differences between treatments which were similar results as previously reported by Ivanovic et al. (2012).

\section{CONCLUSION}

The administration of single probiotic of Lactobacillus plantarum AKK-30 or Saccharomyces cerevisiae B-18 was potential as feed additive to improve physical quality of quail egg, nutrient content of meat and to reduce egg and blood cholesterol content in laying Japanese quail (Coturnix coturnix Japonica).

\section{CONFLICT OF INTEREST}

We state that there is no conflict of interest with any personal, financial, or other relationships with other people or organization related to the material discussed in the manuscript.

\section{ACKNOWLEDGMENTS}

This project was supported by Budget Implementation Registration Form (DIPA) of Research Division for Natural Product Technology-Indonesian Institute of Sciences (BPTBA-LIPI) and The National Priority Research Project (PRN) Project No. 146/E1/PRN/2020 from The Indonesia Endowment Fund for Education (LPDP). Appreciation goes to Ema Damayanti, Hardi Julendra, Mohammad Faiz Karimy, Ade Erma Suryani, Muslih Anwar, Madina Nurohmah, Melisa Ekaningrum, and Diding Ristino for providing proper management and care for this experiment and collecting data processing.

\section{REFERENCES}

Abdel-Moneim, A.M.E., D.A. Selim, H.A. Basuony, E.M. Sabic, A.A. Saleh and T.A. Ebeid. 2020. Effect of dietary supplementation of Bacillus subtilis spores on growth performance, oxidative status, and digestive enzyme activities in Japanese quail birds. Trop. Anim. Health Prod. 52(2): 671-680.

Abou-Kassem, D.E., M.F. Elsadek, A.E. AbdelMoneim, S.A. Mahgoub, G.M. Elaraby, A.E. Taha, M.M.Elshafie, D.M.Alkhawtani, M.E. Abd El-Hack and E.A. Ashour. 2020. Growth, carcass characteristics, meat quality and microbial aspects of growing quail fed diets enriched with two different types of probiotics (Bacillus toyonensis and Bifidobacterium bifidum). Poult. Sci. In Press.

AOAC. 1990. Official methods of analysis. $15^{\text {th }}$ ed. Association of Official Analytical Chemists. Washington DC.

Attia, Y.A., A.E. Abd El-Hamid, H.F. Ellakany, F. Bovera, M.A. Al-Harthi and S.A. Ghazaly. 
2013. Growing and laying performance of Japanese quail fed diet supplemented with different concentrations of acetic acid. Ital. J. Anim. Sci. 12(e37):222-230.

Ayasan, T., B.D. Ozcan, M. Baylan and S. Canogullari. 2006. The effects of dietary inclusion of probiotic protexin on egg yield parameters of Japanese Quails (Cortunix cortunix Japonica). Int. J. Poult.Sci. 5(8): 776-779.

Aziz, Z., S. Cyriac, V. Beena and P.T. Philomina. 2012. Comparison of cholesterol content in chicken, duck, and quail eggs. J. Vet. Anim. Sci. 43: 64-66.

Barbosa-Canovas, G.V., E. Ortega-Rivas, P. Juliano and H. Yan. 2005. Food powders: physical properties, processing, and functionality. Kluwer Academic/Plenum Publishers, New York.

Barzegar, S., S-B. Wu, M. Choct and R.A. Swick. 2020. Factor affecting energy metabolism and evaluating net energy of poultry feed. Poult. Sci. 99(1):487-498.

Cenesiz, S., H. Yaman, A. Ozcan and G. Karademr. 2008. Effect of kefir as probiotic on serum cholesterol, total lipid, aspartate amino transferase and alanina amino transferase activities in broiler chicks. Medycyna Weterynaryjna. 64: 168-170.

Cheng, Q. and D.W. Sun. 2008. Factors affecting the water holding capacity of red med products: A review of recent research advances. Crit. Rev. Food Sci. Nutr. 48: 137-159.

Corcoran, B., R.P. Ross, G.F. Fitzgerald and C. Stanton. 2004. Comparative survival of probiotic lactobacilli spray-dried in the presence of prebiotic substances. J. App. Microbiol. 96: 1024-1039.

CoHort Software. 2008. CoStat Version 6.400. http://www.cohort.com

El-Kelawy, M. and A. Sh. ELnaggar. 2016. Inclusion of Saccharomyces cerevisiae in diet of Japanese quail. 1-effect on growth performance, some blood plasma constituents and carcass characteristics. Egypt. Poult. Sci. J. 36(4):1269-1282.

Genchev, A., G. Mihaylova, S. Ribarski, A. Pavlov and M. Kabakchiev. 2008. Meat quality and composition in Japanese quails. Trakia J. Sci. 6: 72-82.

Gomez, K.A. and A.A. Gomez. 2007. Statistical Procedures for Agricultural Research. $2^{\text {nd }}$ ed. UI Press, Jakarta.
Guclu, B.K. 2011. Effects of probiotic and prebiotic (mannan oligosaccharide) supplementation on performance, egg quality and hatchability in quail breeders. Vet. Fak. Derg. 58: 27-32.

Hamm, R. 1960. Biochemistry of meat hydration. Adv. Food Res. 10: 355-436.

Hassanein, S.M. and N.K. Soliman. 2010. Effect of probiotic (Saccharomyces cerevisiae) adding to diets on intestinal microflora and performance of Hy-Line layers hens. J. Am. Sci. 6(11): 159-169.

Hosseini, S.C. 2011. The effect of utilization of different levels of Saccharomyces cerevisiae on broiler chicken's performance. Global Vet. 6: 233-236.

Huss, D., G. Poynter and R. Lansford. 2008. Japanese quail (Coturnix japonica) as a laboratory animal model. Lab Anim. 37:513-519.

Hussein, E. and S. Selim. 2018. Efficacy of yeast and multi-strain probiotic alone or in combination on growth performance, carcass traits, blood biochemical constituents, and meat quality of broiler chickens. Livest. Sci. 216: 153-159.

Iravani, S., H. Korbekandi and S.V. Mirmohammadi. 2015. Technology and potential applications of probiotic encapsulation in fermented milk products. J. Food Sci. Technol. 52(8): 4679-4696.

Istiqomah, L., M. Anwar, A.S. Anggraeni and E. Damayanti. 2018. Cholesterol assimilation of Saccharomyces cerevisiae B-18 isolated from gastrointestinal tract of Javanese duck. J. Indonesian Trop. Anim. Agric. 43(2): 149158.

Istiqomah, L., S.N. Hayati, E. Damayanti, H. Julendra, A.A. Sakti and T. Untari. 2013. Performance and meat quality of broilers infected with Escherichia coli and administered with bio additive, probiotic, and antibiotic. Media Peternakan 36(1): 1420.

Ivanovic, S., B. Pisinov, D. Maslic-Strizak, B. Savic and Z. Stojanovic. 2012. Influence of probiotics on quality of chicken meat. Afr. J. Agric. Res. 7: 2191-2196.

Julendra, H., A.E. Suryani, L. Istiqomah, E. Damayanti, M. Anwar, and N. Fitriani. 2017. Isolation of lactic acid bacteria with cholesterol-lowering activity from digestive tracts of Indonesian native chickens. Media Peternakan 40: 35-41. 
Kalafova, A., C. Hrncar, K. Zbynovska, O. Bucko, E. Hanusova, Z. Kapustova, M. Schneidgenova, P. Bielik and M. Capcarova. 2018. The effects of dietary probiotics and humic acid on meat quality of Japanese quail including sex-related differences and economical background. Biologia 73:765771.

Kalsum, U., H. Soetanto, Achmanu and O. Sjofjan. 2012. Influence of a probiotic containing Lactobacillus fermentum on the laying performance and egg quality of Japanese quails. Int. J. Poult. Sci. 11(4): 311-315.

Khalifa, M.I. and E.A. Noseer. 2019. Cholesterol quality of edible eggs produced by quail fed diets containing probiotic and/or ginger (Zingiber officinale). Livest. Res. Rur. Dev. 31(10) Article \#165

Kim, H.W., T. Cramer, O.O. Ogbeifun, J.K. Seo, F. Yan, H.W. Cheng and Y.H.B Kim. 2017. Breast meat quality and protein functionality of broilers with different probiotic levels and cyclic heat challenge exposure. Meat Muscle Biol. 1: 81-89.

Leja, K., R. Dembczyński, W. Białas and T. Jankowski. 2009. Production of dry Lactobacillus rhamnosus GG preparations by spray drying and lyophilization in aqueous two-phase systems. Acta Sci. Pol. Technol. Aliment. 8: 39-49.

Lokapirnasari, W.P., A.R. Dewi, A. Fathinah, S. Hidanah, N. Harijani, Soeharsono, B. Karimah and A.D. Andriani. 2017. Effect of probiotic supplementation on organic feed to alternative antibiotic growth promoter on production performance and economics analysis of quail. Vet. World 10(12): 15081514.

Lokapirnasari, W.P., S. Hidanah, Suharsono, A. Fathinah, A.R. Dewi, A.D. Andriani, B. Karimah, T. Nurhajati, K. Soepranianondo and M. Lamid. 2018. Potency of probiotics on HDL, LDL, cholesterol and total protein of egg's quail (Coturnix coturnix japonica). J. Appl. Environ. Biol. Sci. 8: 65-69.

Manafi, S.I. Khalaji and M.I. Hedayati. 2016. Assessment of a probiotic containing Bacillus subtilis on the performance and gut health of laying Japanese quails (Coturnix Coturnix Japonica). Braz. J. Poult. Sci. 18: 599-606.

Nallala, V.S. and K. Jeevaratnam. 2019. Hypocholesterolaemic action of
Lactobacillus plantarum $\mathrm{VJC} 38$ in rats fed a cholesterol-enriched diet. Ann. Microbiol. 69(4): 369-376.

NCD-RisC (NCD Risk Factor Collaboration). 2020. National trends in total cholesterol obscure heterogeneous changes in HDL and non-HDL cholesterol and total-to-HDL cholesterol ratio: a pooled analysis of 458 population-based studies in Asian and Western countries. Int. J. Epidemiol. 49: 173-192.

Nikmaram, P.M.S Yarmand, Z. Emamjomeh and H.K. Darehabi. 2011. Effect of cooking methods on chemical composition, quality and cook loss of camel muscle (Longissimus dorsi) in comparison with veal. Glob. Vet. 6:201-207.

NRC (National Research Council). 1994. Nutrient Requirements of Poultry. $9^{\text {th }}$ Rev. Ed. National Academic Press, Washington DC.

Olgun, O. and A.Ö. Yıldız. 2014. Effects of diets including different levels of protein and supplemented with probiotic-enzyme on performance and eggshell quality of laying quails. Turk. J. Agric. Food Technol. (5): 236-241.

Omar, N.M.F.B.N., A.S. Kamarudin, and N. Huda. 2019. Effect of probiotics (EM-1) addition on quality characteristics of quail meat. Int. J. Eng. Technol. 7: 122-126.

Peters, S.A., Y. Singhateh, D. Mackay, R.R. Huxley and M. Woodward. 2016. Total cholesterol as a risk factor for coronary heart disease and stroke in women compared with men: A systematic review and meta-analysis. Atherosclerosis 248: 123131.

Plummer, D.T. 1987. An Introduction to Practical Biochemistry. Third Edition. Mc.Graw Hill College, London, UK.

Saikia, D., A.K. Manhar, B. Deka, R. Roy, K. Gupta, N.D. Namsa, P. Chattopadhyay, R. Doley, and M. Mandal. 2018. Hypocholesterolemic activity of indigenous probiotic isolate Saccharomyces cerevisiae ARDMC1 in a rat model. J. Food Drug Anal. 26(1): 154-162.

Siadati, S.A., Y. Ebrahimnezhad, G.S. Jouzani and J. Shayegh. 2018. Evaluation of the probiotic potential of some native Lactobacillus strains on the laying performance and egg quality parameters of Japanese quails. Iran. J. App. Anim. Sci. 8:703-712.. 
Silva, J., R. Freixo, P. Gibbs and P. Teixeira. 2011. Spray-drying for the production of dried cultures. Int. J. Dairy Technol. 64: 321-335.

Sjöberg, B.G. 2016. Studies on cholesterol and bile acid metabolism in relation to plasma lipoproteins in humans. Thesis. Karolinska Institute, Stockholm.

Soeparno. 2005. Meat Science and Technology. UGM Press, Yogyakarta.

Tomaro-Duchesneau, C., M.L. Jones, D. Shah, P. Jain, S. Saha and S. Prakash. 2014. Cholesterol assimilation by Lactobacillus probiotic bacteria: an in vitro investigation. BioMed Research Int.. 2014:1-9.

Trembecká, L., P. Haščík, J. Čuboň, M. Bobko, P. Cviková and L. Hleba. 2020. Chemical and sensory characteristics of chicken breast meat after dietary supplementation with probiotic given in combination with bee pollen and propolis. J. Microbiol, Biotechnol. Food Sci. 9(5): 275-280.

Yalçın, S., S. Yalçın, K. Cakın, Ö. Eltan and L. Dağaşan. 2010. Effects of dietary yeast autolysate (Saccharomyces cerevisiae) on performance, egg traits, egg cholesterol content, egg yolk fatty acid composition and humoral immune response of laying hens. J. Sci. Food Agric. 90:1695-1701.

Zhong, S., H. Liu, H. Zhang, T. Han, H. Jia and Y. Xie. 2016. Effects of Kluyveromyces marxianus isolated from Tibetan mushrooms on the plasma lipids, egg cholesterol level, egg quality and intestinal health of laying hens. Braz. J. Poult. Sci. 18(2): 261-268. 